\title{
Hyperthermia Induces Expression of Transforming Growth Factor- $\beta$ s in Rat Cardiac Cells In Vitro and In Vivo
}

Kathleen C. Flanders, Thomas S. Winokur, Michael G. Holder, and Michael B. Sporn

Laboratory of Chemoprevention, National Cancer Institute, Bethesda, Maryland 20892

\begin{abstract}
Hyperthermia causes changes in expression of TGF- $\beta$ mRNA and protein in cultured cardiac cells, as well as in the heart in vivo. $12 \mathrm{~h}$ after hyperthermia, primary cultures of neonatal rat cardiomyocytes show a two- to threefold decreased expression of TGF- $\beta$ mRNAs which returns to control levels by $48 \mathrm{~h}$ after heat shock. In cultures of cardiac fibroblasts, expression of TGF- $\beta$ mRNAs increases 5-25-fold, $12-48 \mathrm{~h}$ after heat shock, while fetal bovine heart endothelial cells show little change in TGF- $\beta$ expression after hyperthermia. In each case, mRNAs for TGF- $\beta \mathrm{s} 1,2$, and 3 are regulated similarly. Hearts isolated from rats exposed to hyperthermia show an initial 20 -fold decrease in TGF- $\beta 1$ and 3 mRNA levels which return to control levels by $24 \mathrm{~h}$ and subsequently are elevated two- to threefold above normal 48-72 $\mathrm{h}$ after heat shock; there is little change in TGF- $\beta 2$ mRNA. Expression of immunoreactive TGF- $\beta 1$ and 3 protein, localized intracellularly in myocytes, follows the same pattern as the mRNA expression. By $72 \mathrm{~h}$, some myocytes show hyperstaining for TGF- $\beta 1$. Staining for extracellular TGF- $\beta 1 / 3$ exhibits the opposite time course, being most intense 3-6 h after heat shock and returning to control levels by $48 \mathrm{~h}$. The increase in TGF- $\beta \mathrm{s}$ after hyperthermia could play a role in mediating the reported cardioprotective effects of heat shock. (J. Clin. Invest. 1993. 92:404-410.) Key words: cardioprotection • heat shock • stress response - growth factors • immunohistochemistry
\end{abstract}

\section{Introduction}

TGF- $\beta$ s are multifunctional proteins that are expressed in a variety of tissues and that affect cell growth and differentiation, expression of extracellular matrix, immune responses, angiogenesis, and soft and hard tissue repair $(1,2)$. Of the five highly homologous TGF- $\beta$ isoforms, only TGF- $\beta$ s 1,2 , and 3 are expressed in mammalian tissues. In many assay systems the TGF- $\beta$ isoforms behave similarly $(3,4)$, but some differences in activity are seen in regulating mesoderm induction in Xenopus (3), and growth and function of endothelial cells (5), embryonic neurons (6), and astrocytes (K. Flanders, unpublished observations). In addition, antisense oligodeoxynucleotides to TGF- $\beta 3$, but not TGF- $\beta$ s 1 or 2 , inhibit epithelial-mesenchymal transformation in embryonic cardiac endothelial cells (7),

Dr. Flanders and Dr. Winokur are co-senior authors of this article. Address correspondence to Dr. Kathleen C. Flanders, National Institutes of Health, Building 41 / Room C-629, Bethesda, MD 20892

Received for publication 22 December 1992 and in revised form 25 February 1993.

J. Clin. Invest.

(c) The American Society for Clinical Investigation, Inc.

0021-9738/93/07/404/07 \$2.00

Volume 92, July 1993, 404-410 suggesting that there may be isoform-specific effects of TGF- $\beta$ s in the heart.

TGF- $\beta$ s are expressed in embryonic ( 8-10) and adult heart (9-11) and the immunohistochemical staining pattern for TGF- $\beta 1$ protein changes after myocardial infarct in rats (11). Treatment of neonatal rat myocytes with TGF- $\beta$ can induce the expression of contactile protein genes which are upregulated in hypertrophy (12) and maintain the beating rate of cells treated with IL-1 (13). Lefer et al. (14) using a rat myocardial infarct model, also have demonstrated cardioprotective effects of TGF- $\beta$ given at the time of reperfusion which results in decreased creatine kinase release from the heart, indicating a lesser degree of cardiac damage.

Hyperthermic treatment, as well as a variety of other physiological stresses, induce the rapid synthesis of a family of heat shock proteins (HSPs) ${ }^{1}$ which are believed to protect cellular function by removing malfolded proteins (15-17). Hyperthermia $(18,19)$, ischemia (19-21), exercise (22), treatment with heavy metals (23), and hemodynamic overload (24) all have been shown to induce HSP expression in myocytes. The accumulation and subsequent degradation of HSPs are correlated with the development of thermotolerance $(15,25,26)$ whereby cells exposed to an initial nonlethal stress are better able to withstand a second potentially lethal stress. The mechanisms by which increased expression of HSPs leads to thermotolerance are not well understood. Thus, Donnelly et al. (19) report reduced infarct size in rats subjected to ischemia-reperfusion $24 \mathrm{~h}$ after hyperthermia, as compared to controls. Additionally, Karmazyn et al. (27) report that hearts taken from rats 24-48 $\mathrm{h}$ after heat shock show a greater recovery of contractile force after ischemia-reperfusion in an isolated perfused heart system than do hearts from control rats. As with addition of TGF $-\beta$ to the ischemia-reperfusion model (14), the hearts from heat-shocked animals show less loss of creatine kinase than controls (27). Both studies indicate that some of the protective effects may be mediated by decreased production of oxygen free radicals $(14,27)$.

The similarity of the cardioprotective effects of TGF- $\beta$ and heat shock suggests a relationship between these two families of proteins. Here we show that hyperthermia changes expression of TGF- $\beta$ s in cardiac myocytes and fibroblasts, but not endothelial cells in vitro, and that in vivo, the time course of increased expression of TGF- $\beta$ s 1 and 3 in the heart after hyperthermia parallels that of the cardioprotective effects of hyperthermia.

\section{Methods}

Cell culture. Neonatal rat cardiomyocytes were prepared from the left ventricles of 2-d-old rat pups as described by Roberts et al. (13). Briefly, after a differential plating to remove fibroblasts, myocytes were further purified on a gradient system consisting of Percoll (Sigma Im-

1. Abbreviations used in this paper: FBHE, fetal bovine heart endothelial; HSP, heat shock protein. 
munochemicals, St. Louis, MO) in MEM (Gibco Laboratories, Grand Island, NY) adjusted to final densities of $1.082,1.061$, and $1.050 \mathrm{~g} / \mathrm{ml}$. The purified myocytes banding between 1.082 and $1.061 \mathrm{~g} / \mathrm{ml}$ layers were cultured in DMEM/F12 containing 10-15 mM Hepes (Gibco) and supplemented with $5 \%$ calf serum, penicillin $(50 \mathrm{U} / \mathrm{ml})$ and streptomycin $(50 \mu \mathrm{g} / \mathrm{ml})$. Myocytes were plated at a density of $2.2 \times 10^{6}$ cells $/ 60-\mathrm{mm}$ dish and were used $72 \mathrm{~h}$ after plating when $\sim 90 \%$ of the cells are myocytes ( $T$. Winokur, unpublished observation). Cardiac fibroblasts were grown in the same medium and were used when they had grown to confluence after the second passage. Fetal bovine heart endothelial cells (FBHE) were from the American Type Culture Collection (Rockville, MD) and were grown in DMEM supplemented with $10 \%$ calf serum, penicillin-streptomycin, and $5 \mu \mathrm{g} / \mathrm{ml}$ endothelial cell mitogen (Biomedical Technologies Inc., Stoughton, MA). Hyperthermic treatment was initiated for all cells by feeding with fresh media and transferring them to a $95 \% \mathrm{CO}_{2} / 5 \% \mathrm{O}_{2}$ incubator at $41.5^{\circ}$ for $2 \mathrm{~h}$. Cells were then placed in a $37^{\circ}$ incubator to recover for various times and then either extracted for preparation of mRNA or metabolically labeled for immunoprecipitation studies.

In vivo hyperthermia. Rats were cared for and used in experimental protocols in accordance with the National Cancer Institute Animal Care and Use Committee. Male Sprague-Dawley rats ( $225 \mathrm{~g}$; Taconic Farms, Inc., Germantown, NY) were subjected to hyperthermia following a protocol similar to that of Currie et al. (18). Animals were anesthetized with sodium pentobarbital $(40 \mathrm{mg} / \mathrm{kg}$, intraperitoneally) and placed on a water-jacketed heating pad set at $55^{\circ}$ until their core temperature reached $41.5^{\circ}$ as monitored with a rectal thermometer. After $15 \mathrm{~min}$ at this temperature, rats were returned to cages and allowed to recover. Control rats were anesthetized, but not heated. At various times rats were killed by $\mathrm{CO}_{2}$ asphyxiation and the heart and lungs were quickly excised. A small piece of each tissue was placed in $10 \%$ neutral buffered formalin for immunohistochemistry. The remaining tissue was minced and homogenized in guanidinium isothiocyanate with beta-mercaptoethanol for extraction of mRNA.

Expression of heat shock proteins. Cultured cells were subjected to hyperthermia for up to $2 \mathrm{~h}$ as described above and then were changed into medium containing $5 \%$ of the normal concentration of methionine along with $25 \mu \mathrm{Ci}\left[{ }^{35} \mathrm{~S}\right.$ ] methionine $/ 2 \mathrm{ml}$ per dish (Amersham Corp., Arlington Heights, IL). After a $1-\mathrm{h}$ incubation at $37^{\circ}$, the medium was removed from the cells which were then rinsed twice with cold PBS and extracted into sample buffer containing beta-mercaptoethanol (28). Extracts were sonicated and boiled for $5 \mathrm{~min}$. Equal numbers of TCA-precipitable counts were run on 7.5\% SDS-polyacrylamide gels according to Laemmli (28). Gels were fixed, enhanced with Enlightening (NEN/Dupont, Boston, MA), dried, and exposed to xray film at $-70^{\circ}$. As a positive control for expression of HSPs, cells were treated overnight at $37^{\circ}$ in arginine-free medium containing 125 $\mu \mathrm{g} / \mathrm{ml}$ canavanine (29). Control cells remained at $37^{\circ}$ and were labeled with $\left[{ }^{35} \mathrm{~S}\right]$ methionine as described above.

Preparation of RNA and Northern blotting. Total cellular mRNA was prepared from tissues and cultured cells by the method of Chomczynski and Sacchi (30). $10 \mu \mathrm{g}$ of total mRNA was electrophoresed on $1 \%$ agarose-formaldehyde gels and then transferred to Nytran (Schleicher and Schuell, Keene, NH). After ultraviolet cross-linking, filters were prehybridized, hybridized, and washed at $65^{\circ}$ according to Church and Gilbert ( 31 ). Insert cDNA probes were labeled with [ $\left.{ }^{32} \mathrm{P}\right]-$ dCTP by random primed labeling (BRL, Gaithersburg, MD) and included: rat TGF- $\beta 1$ (32), murine TGF- $\beta$ s 2 (9), and 3 (33), ( 1 kb HindIII-Xbal fragments including the entire coding region of the TGF$\beta s$ ), a 1.4-kb PstI-PstI fragment of Chinese hamster HSP 70 (34) (provided by Dr. A. Fornace, National Institutes of Health), and a $0.8-\mathrm{kb}$ PstI-PstI fragment of rat IGF-II (35) (provided by Dr. M. Rechler, National Institutes of Health). Blots were exposed to $\mathrm{x}$-ray film at $-70^{\circ}$. Quantitation by transmittance densitometry was performed on a laser densitometer (model 2202; LKB/Pharmacia, Piscataway, NJ) equipped with an integrator. Sample loading was normalized by scanning negatives of photographs showing 28 and 18S RNA detected by ethidium bromide.
Immunoprecipitation of radiolabeled TGF- $\beta$ s 1 and 2. Cultured cells subjected to hyperthermia for $2 \mathrm{~h}$ were allowed to recover at $37^{\circ}$ for various times and then were incubated for $16 \mathrm{~h}$ in medium containing $5 \%$ of the normal concentration of methionine and cysteine supplemented with $300 \mu \mathrm{Ci} / 60-\mathrm{mm}$ dish of $\left[{ }^{35} \mathrm{~S}\right]$ cysteine. The medium was collected and immunoprecipitated as described by Robey et al. (36) with rabbit anti-human TGF- $\beta 1$ (37) or rabbit anti-porcine TGF- $\beta 2$ (38). Specificity was demonstrated by preincubating the primary antibody with $200 \mathrm{ng}$ of the appropriate TGF- $\beta$ before using it for immunoprecipitation. Samples were run on nonreducing $10 \%$ SDS-polyacrylamide gels which were then fixed and enhanced with 2,5-diphenyloxozole dissolved in DMSO. Gels were dried and exposed to x-ray film at $-70^{\circ}$.

Detection of TGF- $\beta$ s by immunohistochemistry. Heart and lung tissues were fixed overnight in $10 \%$ neutral buffered formalin and then for 4-6 $\mathrm{h}$ in Bouin's solution (Sigma Immunochemicals). Tissues were embedded in paraffin and 5- $\mu \mathrm{m}$ sections were stained using the avidinbiotin peroxidase method with an ABC Elite kit (Vector Labs, Burlingame, CA) as described by Flanders et al. (39). Rabbit polyclonal primary antibodies used included: anti-CC (1-30-1) raised to a peptide corresponding to the amino terminal 30 amino acids of TGF- $\beta 1$ which stains extracellular TGF- $\beta 1$ (39), anti-pre 267-278-1 raised to amino acids $267-278$ of the TGF- $\beta 1$ precursor (40), anti-50-75-2 raised to amino acids 50-75 of mature TGF- $\beta 2$ ( 41 ), and anti-50-60-3 raised to amino acids $50-60$ of mature TGF- $\beta 3$ (6). Anti-CC $1-30-1$ is a total IgG fraction, while the other antibodies were affinity purified against the immunizing peptide and all were used at IgG concentrations of $<3$ $\mu \mathrm{g} / \mathrm{ml}$. In Western blot analysis anti-pre TGF- $\beta 1$ and anti-TGF- $\beta 3$ react only with the TGF- $\beta$ isoform to which they were raised. AntiTGF- $\beta 2$ cross-reacts with TGF- $\beta 3$ in Western blots, but not in an ELISA. Cross-reactivity of this antibody in tissues under our staining conditions appears to be minimal, since some tissues react with antiTGF- $\beta 3$, but not with anti-TGF- $\beta 2$ (42). Anti-CC (1-30-1) reacts slightly with TGF- $\beta 3$ in Western blots and cross-reactivity in tissues sections has not been ruled out. Specificity controls included using normal rabbit serum IgG at $3 \mu \mathrm{g} / \mathrm{ml}$ as the primary antibody or incubating the primary antibody with a 20 -fold molar excess of immunizing peptide before applying it to the section.

\section{Results}

Heat shock induces changes in expression of TGF- $\beta$ s in cultured cardiac cells. Incubation of neonatal rat myocytes, cardiac fibroblasts, and FBHE cells for $2 \mathrm{~h}$ at $41.5^{\circ}$ is sufficient to induce expression of HSPs in all three cell types as shown in Fig. 1. In each cell type, induction of a HSP of $68 / 70 \mathrm{kD}$ is seen after $40 \mathrm{~min}$ of heat shock and expression increases through 120 min of heat shock. Cardiac fibroblasts and myocytes also express a $90-\mathrm{kD}$ HSP. As a control, cells were treated with canavanine, an arginine analogue, which also induces expression of HSPs (29). Canavanine treatment results in elevated expression of the same proteins as does hyperthermia.

Heat shock alters mRNA expression of TGF- $\beta$ s 1,2 , and 3 , and Fig. 2 shows a Northern blot of TGF- $\beta 2$ hybridization which is representative of the responses of TGF- $\beta 1$ and 3 mRNAs. The expression of each of the three TGF- $\beta$ isoforms follows a qualitatively similar pattern in each cell type, but there are differences between the three cell types. In myocytes, there is an initial decrease in TGF- $\beta$ expression at $6-12 \mathrm{~h}$ which returns to control levels by $48 \mathrm{~h}$. In cardiac fibroblasts, TGF- $\beta$ expression increases by $12 \mathrm{~h}$ and remains elevated through $72 \mathrm{~h}$ after heat shock, while in FBHE cells there is little change in TGF- $\beta$ mRNA expression after hyperthermia.

The results of densitometric scans of the Northern blots to determine message levels in treated cells as compared to con- 


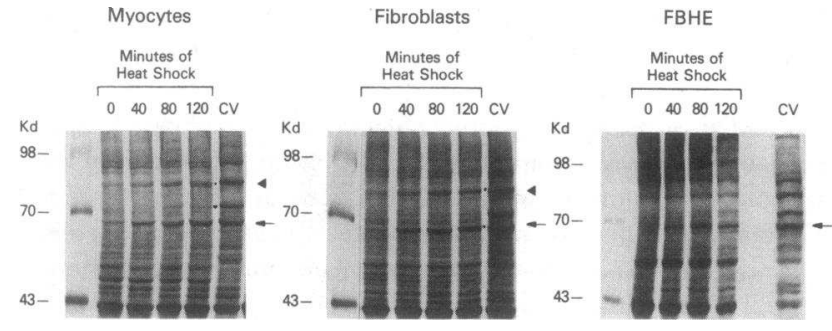

Figure 1. Induction of HSPs in cultured cardiac cells. Cells were subjected to hyperthermia for the indicated times or treated overnight with canavanine $(\mathrm{CV})$. Radiolabeled cellular proteins were separated on $7.5 \%$ polyacrylamide gels. In all cell types, hyperthermia and canavanine induce expression of an HSP with a molecular mass of $\sim 70$ $\mathrm{kD}$ (blunt arrow), while in myocytes and cardiac fibroblasts, an HSP of $90 \mathrm{kD}$ (sharp arrow) is also induced.

trols are shown in Fig. 3. The reported values are normalized to the level of ethidium bromide stain of 18 and $28 \mathrm{~S}$ RNA to account for slight loading differences. For FBHE cells, control (non-heat shocked) cells were processed at each recovery time point, because as can be seen in Fig. 2, there are changes in expression levels of TGF- $\beta$ s in control cells with time, possibly due to depletion of the endothelial cell mitogen which is necessary for cell survival (43). Experiments showed that the expression of TGF- $\beta$ mRNA did not change with time in control myocytes or cardiac fibroblasts (not shown). For these cells, the controls were processed at the $24 \mathrm{~h}$ recovery time.

The levels of TGF- $\beta 2$ protein, as a fraction of total protein secreted by cells increased in agreement with the mRNA response to heat shock (Fig. 4), while there was less change in

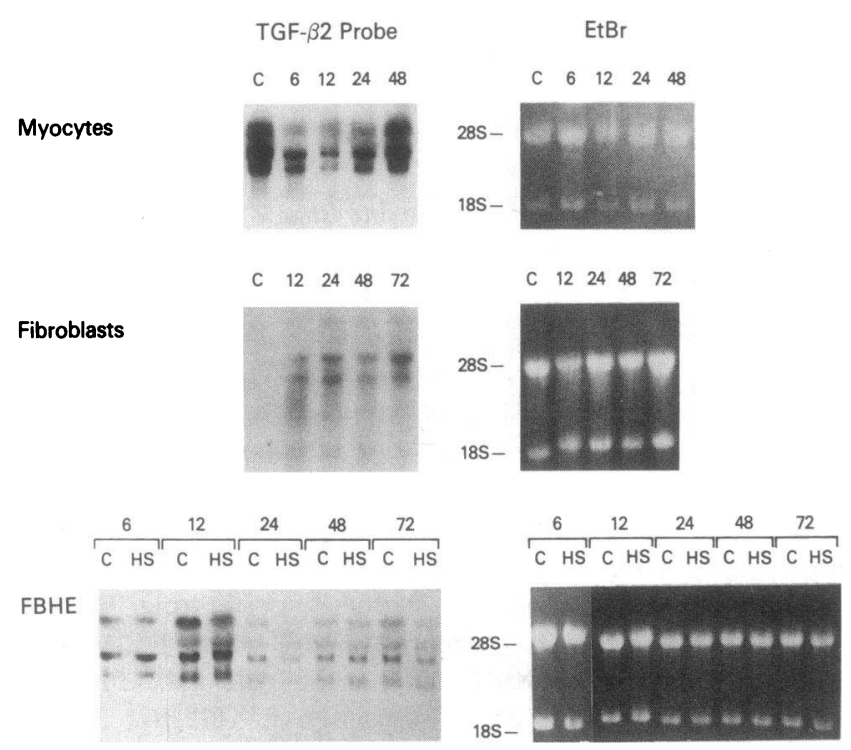

Figure 2. Northern blots of expression of TGF- $\beta 2$ mRNA after hyperthermia of cultured cells. Cells were allowed to recover for the indicated times after hyperthermia. Total mRNA ( $10 \mu \mathrm{g} /$ lane $)$ isolated from the cells was run on agarose gels, transferred to Nytran (Schleicher and Schuell) and hybridized with ${ }^{32}$ P-labeled TGF- $\beta 2$ cDNA. Ethidium bromide ( $E t B r)$ staining of $28 \mathrm{~S}$ and $18 \mathrm{~S}$ mRNA was used to judge equivalence of loading. Results are representative of two full and several partial time course experiments for each cell type. Blots were also probed with cDNAs for TGF- $\beta$ s 1 and 3 with similar results.

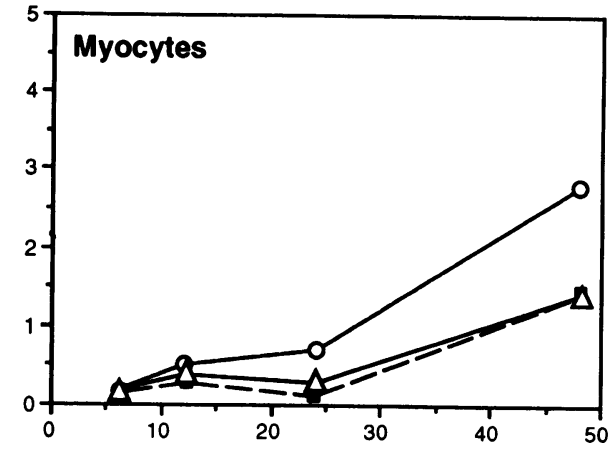

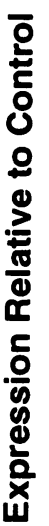
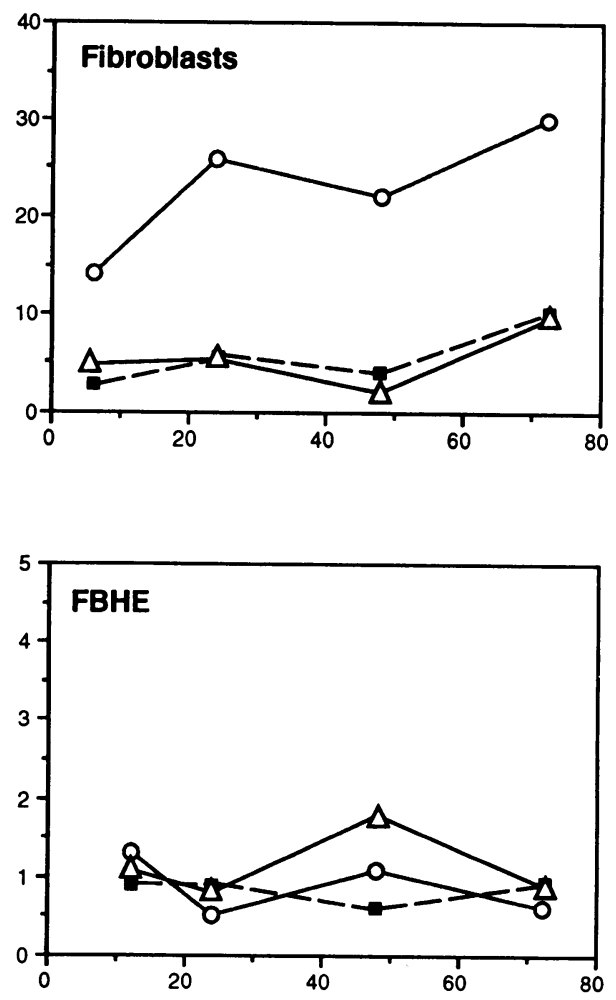

Time (hours)

Figure 3. Changes in mRNA expression of TGF- $\beta$ s 1,2 , and 3 after hyperthermia in cultured cells. Densitometric scans of Northern blots generated as described in Fig. 2 for TGF- $\beta$ s $1(\Delta), 2(0)$, and $3(\bullet)$ were normalized to scans of ethidium bromide-stained $28 \mathrm{~S}$ and 18 $\mathrm{S}$ mRNA to account for small differences in loading of gels. To determine the expression relative to control, peak areas of bands from mRNAs prepared from cells recovering from hyperthermia were compared to peak areas of bands from mRNA from cells not subjected to heat shock. Note difference of scale for $y$ axis of fibroblast graph.

TGF- $\beta 1$ protein secretion (not shown). Cells were allowed to recover at $37^{\circ}$ after heat shock until changes in mRNA expression for TGF- $\beta$ s had occurred ( $16 \mathrm{~h}$ for myocytes, $6 \mathrm{~h}$ for fibroblasts, and $3 \mathrm{~h}$ for FBHE cells). Cells were then labeled for $16 \mathrm{~h}$ with $\left[{ }^{35} \mathrm{~S}\right] \mathrm{Cys}$ and the medium was immunoprecipitated with anti-TGF- $\beta 1$ or anti-TGF- $\beta 2$. At present no antibody is available to precipitate endogenous TGF- $\beta 3$ specifically. In cardiac myocytes there is decreased secretion of TGF- $\beta 2$ protein and 


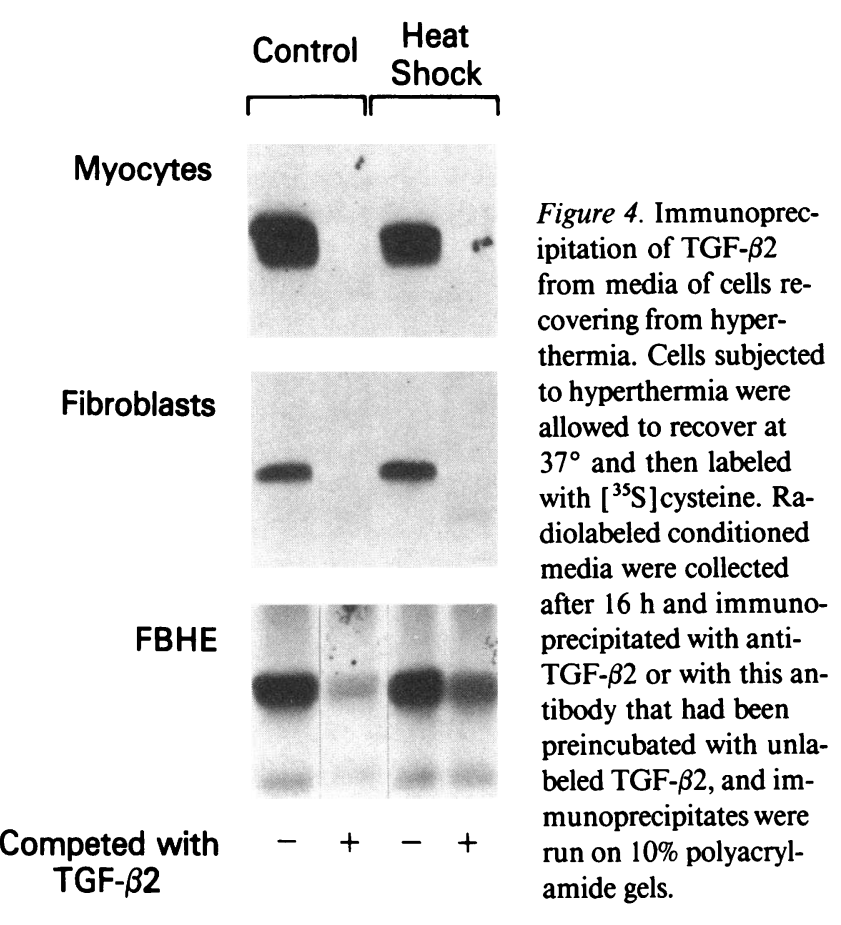

little change in TGF- $\beta 1$ protein. Cardiac fibroblasts showed a slight increase in TGF- $\beta 2$ secreted into the media with no change in TGF- $\beta 1$. However, total protein secretion by the heat-shocked fibroblasts seems to be approximately five-fold lower than in control cells. This is based on levels of radiolabeled proteins which are nonspecifically immunoprecipitated with the antibody. This translates into a six-fold increase in TGF- $\beta 2$ production secreted by the cells relative to other cellular proteins. FBHE cells, which show little change in TGF- $\beta$ mRNA after hyperthermia, also show little change in TGF- $\beta$ protein secretion.

Effects of heat shock on cardiac TGF- $\beta$ expression in vivo. The core temperature of rats was raised to $41.5^{\circ}$ for $15 \mathrm{~min}$ and the animals were allowed to recover for various times. The Northern blot in Fig. 5 shows that for TGF- $\beta \mathrm{s} 1$ and 3, mRNA expression in heart decreases initially and is $<5 \%$ of control levels at $3 \mathrm{~h}$ after heat shock and $30-40 \%$ at $6 \mathrm{~h}$ after heat shock. By $24 \mathrm{~h}$, mRNA expression is close to control levels and at $48 \mathrm{~h}$ is two- to three-fold above control levels. TGF- $\beta 2$ mRNA expression shows less difference in levels between control and heat-shocked animals, showing only a two-fold decrease at the $3 \mathrm{~h}$ time point and a slight increase above control only at $6 \mathrm{~h}$. Expression patterns of IGF-II, another cardiac peptide growth factor, are different from the TGF- $\beta \mathrm{s}$ with an initial increase above control levels at $3 \mathrm{~h}$, a four-fold decrease at $6 \mathrm{~h}$, and a slight elevation at 48-72 h. Fig. 5 also shows that mRNA for HSP 70 is increased dramatically $3 \mathrm{~h}$ after heat shock, but returns to control levels by $6 \mathrm{~h}$, confirming that our hyperthermia protocol was sufficient to induce the heat-shock response. The expression levels of mRNAs for TGF- $\beta$ s 1,2 , and 3 in lung show less dramatic differences between control and heat shocked tissues (data not shown).

The effects of heat shock on the expression of TGF- $\beta$ protein in the heart were investigated by immunohistochemistry. Staining for immunoreactive TGF- $\beta$ s was seen mostly in myocytes or associated with the extracellular matrix, depending on the antibody used, with little discernible staining in cardiac fibroblasts. The most dramatic changes in protein levels are seen with TGF- $\beta 1$ as demonstrated in Fig. 6. Using an antibody which reacts with the pro region of the TGF- $\beta 1$ precursor, and is likely to stain TGF- $\beta$ at sites of synthesis, there is an initial loss of intracellular staining in the myocytes of heatshocked hearts (Fig. $6 \mathrm{~B}$ ) as compared to controls (Fig. $6 \mathrm{~A}$ ) 3-6 h after hyperthermia. By $24 \mathrm{~h}$ after heat shock, the intracellular staining begins to increase toward control levels and by 48-72 h some myocytes are also hyperstained (Fig. $6 C$ ). A negative control where the primary antibody is preincubated with immunizing peptide is shown in the Fig. $6 A$ inset. Using an antibody raised to a peptide sequence in mature TGF- $\beta 1$, which stains principally extracellular TGF- $\beta$ that is released from cells, there is an initial increase in immunoreactivity at early time points (3-6 h) (Fig. 6E) as compared to hearts from control animals (Fig. $6 D$ ). This extracellular staining returns to control levels by $48 \mathrm{~h}$ (Fig. $6 F$ ). The normal rabbit serum IgG control shown as an inset to Fig. $6 D$ shows that some of the light staining in myocytes with this antibody is also present in the control.

When sections are stained with anti-TGF- $\beta 2$ there is little difference in expression of TGF- $\beta 2$ protein between control and heat-shock hearts (data not shown) as predicted from the mRNA data. The staining pattern with the TGF- $\beta 3$ antibody is similar to, but less dramatic than that seen with anti-pre-TGF$\beta 1$; there is a patchy loss of staining initially which returns to control levels by $48 \mathrm{~h}$ (data not shown). Even though TGF $\beta \mathrm{s} 1$ and 3 show comparable changes in mRNA expression in the heart after heat shock, the less dramatic difference in immunostaining seen for TGF- $\beta 3$ may be because TGF- $\beta 3$ protein is not expressed as well after hyperthermia. The $5^{\prime}$ untranslated region of TGF- $\beta 3$ has been shown to inhibit its translation (44) and unique sequences in these regions of TGF- $\beta$ s 1 and 3 could result in different posttranscriptional regulation of protein synthesis for these two isoforms following hyperthermia. Blocking of TGF- $\beta 2$ and 3 antibodies with immunizing peptide before staining abolished immunoreactivity. In agreement with the

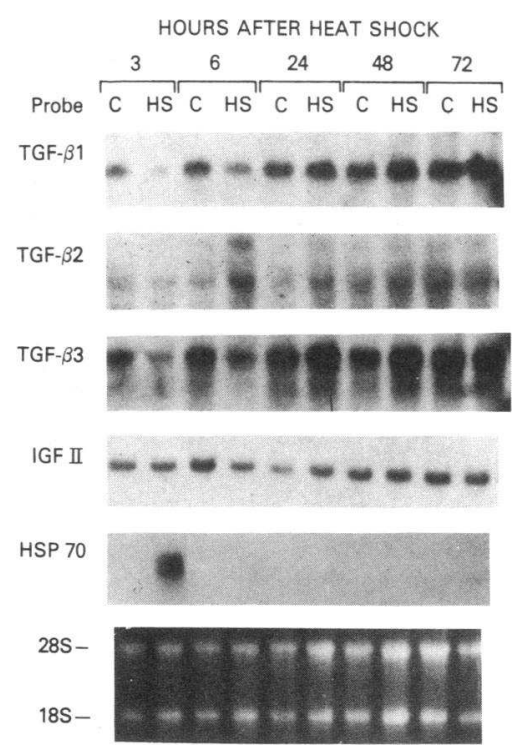

Figure 5. Expression of mRNAs in rat heart during recovery from hyperthermia. mRNA prepared from the hearts at various times after hyperthermic treatment of rats $(H S)$ was run on agarose gels and transferred to $\mathrm{Ny}$ tran (Schleicher and Schuell). Filters were hybidized with ${ }^{32} \mathrm{P}$-labeled cDNAs listed in the figure, washed, and exposed to $x$-ray film. The level of RNA expression after heat shock was compared to RNA from the nonheat shocked control at each time point. Induction levels were corrected for RNA loading as determined by densitometry of ethidium bromide-stained $28 \mathrm{~S}$ and 18S RNA. 

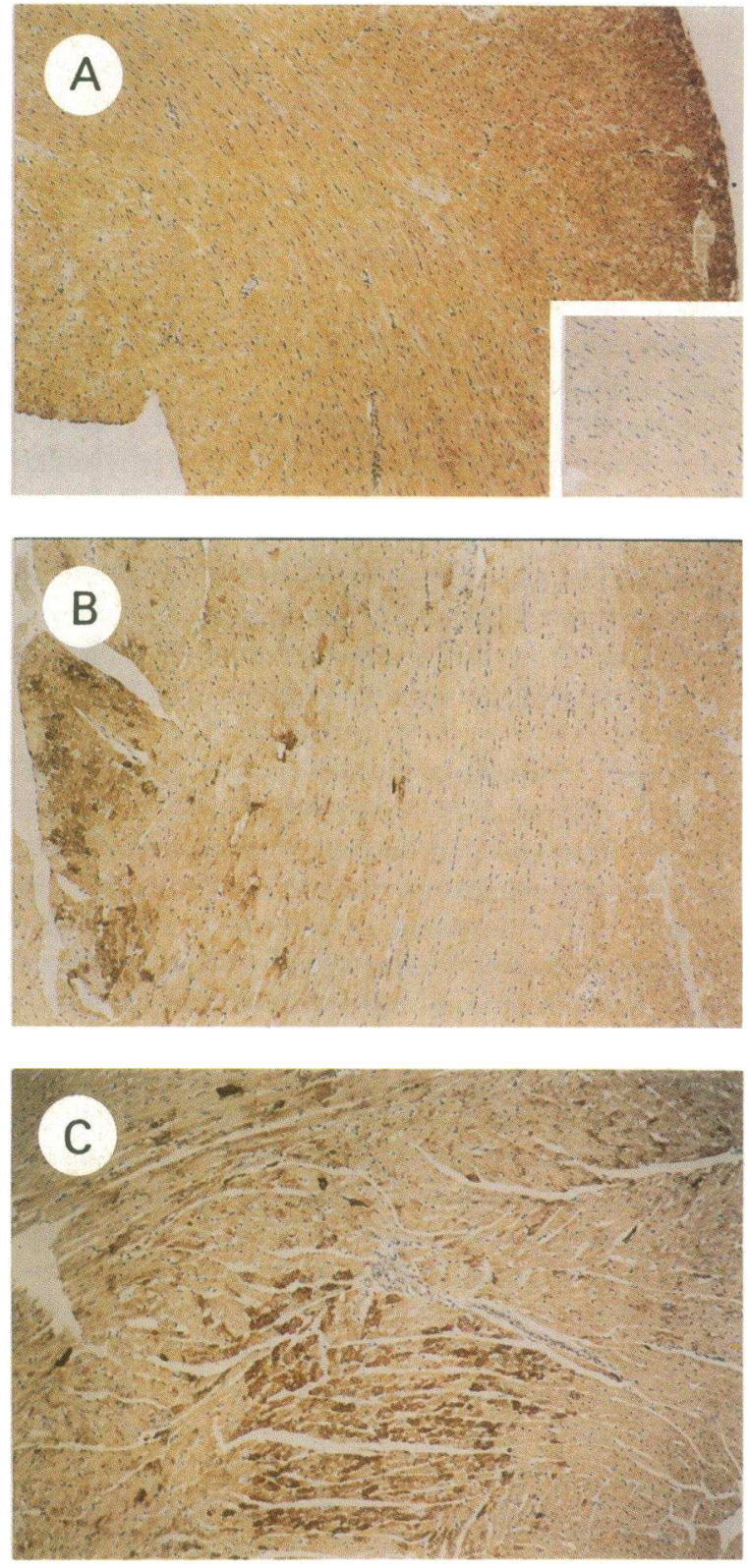
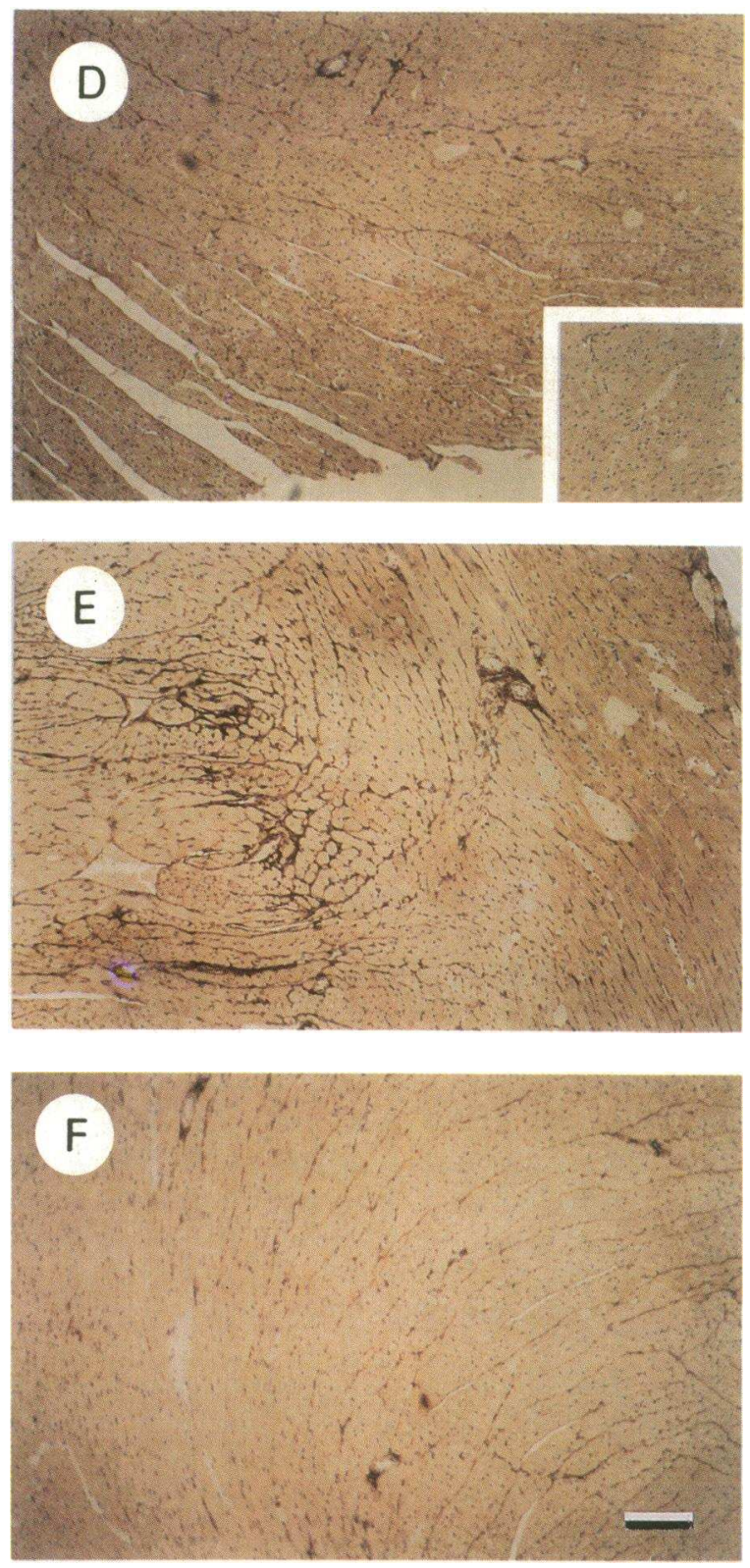

Figure 6. Localization of TGF- $\beta 1$ in heart after hyperthermia. Hearts from rats subjected to hyperthermia as described in Fig. 5 were stained with anti-pre-TGF- $\beta 1(A-C)$ or anti-CC $(D-F)$. There was uniform staining of myocytes in control hearts $(A)$ which was decreased $3 \mathrm{~h}$ after hyperthermia $(B)$ and was elevated above control levels in some regions of the heart $72 \mathrm{~h}$ after hyperthermia $(C)$. Anti-CC showed extracellular staining in control hearts $(D)$ which was increased $3 \mathrm{~h}$ after hyperthermia $(E)$ and had returned to control levels by $48 \mathrm{~h}(F)$. The inset of panel A shows reduction in staining when anti-pre-TGF- $\beta 1$ is preincubated with immunizing peptide and the inset of panel D shows light background staining of myocytes with normal rabbit serum IgG. Peroxidase, with Mayer's hematoxylin. Bar, $100 \mu \mathrm{m}$.

mRNA results, staining of TGF- $\beta$ proteins in lung from control and heat-shocked animals was similar.

\section{Discussion}

Our study demonstrates that hyperthermia can alter levels of TGF- $\beta$ mRNA and protein in cultured cardiac cells, as well as in the heart in vivo. This is not a generalized response either in vitro or in vivo. Primary cultures of cardiomyocytes and cardiac fibroblasts show changes in TGF- $\beta$ expression after heat shock, while the FBHE cell line does not. This may simply reflect differences between the behavior of cell lines, which have adapted to the stress of being grown in monolayer, and primary cells which are more responsive to environmental changes, or alternatively, it may reflect intrinsic differences in the response patterns of these cell types. In vivo, hyperthermia generally increases TGF- $\beta$ expression in the heart, while there is little change in expression in lung from the same animals. We have shown that expression of the mRNA for IGF-II, another cardiac growth factor, also is elevated after heat shock, but with a different time course, suggesting that various growth factors and cytokines may have different functions in the heart after hyperthermia.

There were several differences between the cellular expression pattern of TGF- $\beta$ in response to hyperthermia in vitro and in vivo. In vitro, mRNAs for the three isoforms of TGF- $\beta$ 
change coordinately in all three cell types, while in vivo, TGF$\beta 1$ and 3 mRNA and protein change coordinately with little alteration in TGF- $\beta 2$ mRNA and protein. Secondly, there are differences in expression patterns of TGF- $\beta$ s in different cell types in vitro and in vivo. Both cultured cardiomyocytes and whole heart show an initial decrease in mRNA expression after hyperthermia which returns to, and in the intact heart eventually surpasses, control levels. Immunohistochemical localization of TGF- $\beta 1$ and 3 protein in the heart shows that intracellular staining is found largely in myocytes and that changes in protein expression are similar to those of the mRNA levels. However, in vitro, cardiac fibroblasts show increased expression of TGF- $\beta$ s following hyperthermia, while in the heart, little staining is seen in fibroblasts with no detectable increase in staining following heat shock.

There are interesting differences in immunohistochemical staining patterns in the heart when using an antibody raised to a peptide in the pro region of the TGF- $\beta 1$ precursor (which probably recognizes TGF- $\beta 1$ at sites of synthesis), as compared to an antibody raised to a peptide in mature TGF- $\beta 1$ (which generally localizes extracellular TGF- $\beta 1$ ) (39). The latter antibody also may cross-react with TGF- $\beta 3$ (42). The intracellular staining in myocytes detected with both the TGF- $\beta 1$ pro region antibody and with anti-TGF- $\beta 3$, shows an initial decrease after heat shock and then eventually exceeds control staining by 48-72 h. The extracellular staining shows the opposite response, being highest at early times (3-6 h after heat shock) and then returning to control levels. This increase in extracellular immunoreactivity may represent TGF- $\beta$ protein that has been released from cells damaged by heat shock and is subsequently bound to the extracellular matrix. The increase in intracellular staining in the myocytes after hyperthermia is reminiscent of the enhanced TGF- $\beta 1$ immunoreactivity in surviving myocytes after myocardial infarction in rats (11). In both instances, a subpopulation of cells shows hyperstaining for intracellular TGF- $\beta 1$. In each case, the increased production of TGF- $\beta$ may represent a response to injury that serves to initiate repair of cells damaged by either heat shock or ischemic insult.

Treatment of secondary cultures of chick embryo cells with TGF- $\beta$ in serum-free medium induces expression of HSPs 70 and 90 (45). In preliminary studies, we have not observed increases in HSPs 70 or 90 in cardiomyocytes or cardiac fibroblasts after TGF- $\beta$ administration, but an extensive survey of treatment conditions has not been completed. However, IL-1, IL-2, IL-3, IL-6, and TNF have been shown to induce synthesis of a $30-\mathrm{kD}$ stress protein in cultured cardiomyocytes while in addition, IL-1 induces expression of a 70-kD HSP (46). The increased levels of HSPs could in turn increase TGF- $\beta$ expression, which may be involved in mediating reported cardioprotective effects of TNF- $\alpha$ (47) and IL-1 (48).

The increase in TGF- $\beta$ mRNA and protein in the heart after heat shock occurs in a similar time frame to the reported cardioprotective effects of heat shock. Karmazyn et al. (27) have shown that hearts from rats $48 \mathrm{~h}$ after heat shock show a greater recovery of contractile force after ischemia-reperfusion injury than do hearts from control rats and Donnelly et al. (19) show decreased infarct size in similar experiments in vivo. The report by Lefer et al. (14) that TGF- $\beta$ administered to rats either before or immediately after ischemic injury, but before reperfusion, decreases the extent of damage to the heart suggests that increased levels of TGF- $\beta$ after heat shock could mediate the cardioprotective effects of hyperthermia. We are currently evaluating this hypothesis by repeating the experiments of Karmazyn et al. (27) in the presence of TGF- $\beta$ antibodies to examine the possible involvement of TGF- $\beta$ in the establishment of thermotolerance.

Thermotolerance can generally be defined as the ability of an organism to withstand an otherwise lethal stress due to pretreatment with a nonlethal stress. The stress could result from a number of insults $(25,26$, and references therein ) such as hyperthermia, oxidative injury, or treatment with heavy metals, all of which induce expression of HSPs as an acute response. However, the mechanisms by which HSPs generate the more long-term protective effect of thermotolerance are not well understood. The well-recognized role of TGF- $\beta$ as a mediator of wound healing and tissue repair (1), suggests its increased expression after a perturbation of cellular homeostasis could be beneficial in promoting recovery of cells from a variety of physiologic stresses. This increased expression of TGF- $\beta$ s is observed after experimentally induced wounds in heart (11), brain (49), liver, bone, lung, and kidney (reviewed in reference 50 ). We propose that the increased level of TGF- $\beta$ seen in the heart after hyperthermia is part of a complex cellular program which establishes thermotolerance and attempts to protect cells from further insult. The exact function of TGF- $\beta$ in the thermotolerance program, and its resulting cardioprotective effects, are currently being investigated.

\section{Acknowledgments}

We wish to thank Anita Roberts, Nanette Roche, and Larry Mullen for help in preparing cultures of cardiomyocytes and cardiac fibroblasts.

\section{References}

1. Roberts, A. B., and M. B. Sporn. 1990. The transforming growth factor- $\beta$ s. In Handbook of Experimental Pharmacology, Peptide Growth Factors and their Receptors. Vol. 95, part 1. M. B. Sporn and A. B. Roberts, editors. Springer-Verlag, Heidelberg. 419-472.

2. Massagué, J. 1990. The transforming growth factor- $\beta$ family. Annu. Rev Cell Biol. 6:597-641.

3. Roberts, A. B., F. Rosa, N. S. Roche, J. E. Coligan, M. Garfield, M. L. Rebbert, P. Kondaiah, D. Danielpour, J. H. Kehrl, S. W. Wahl, et al. 1990. Isolation and characterization of TGF- $\beta 2$ and TGF- $\beta 5$ from media conditioned by Xenopus XTC cells. Growth Factors. 2:135-147.

4. ten Dijke, P., K. K. Iwata, C. Goddard, C. Pieler, E. Canalis, T. L. McCarthy, and M. Centrella. 1990. Recombinant transforming growth factor type $\beta 3$ : biological activities and receptor-binding properties in isolated bone cells. Mol. Cell. Biol. 10:4473-4479.

5. Jennings, J. C., S. Mohan, T. A. Linkhart, R. Widstorm, and D. J. Baylink. 1988. Comparison of the biological activities of TGF- $\beta 1$ and TGF- $\beta 2$ : differential activity in endothelial cells. J. Cell. Physiol. 137:167-172.

6. Flanders, K. C., G. Lüdecke, S. Engels, D. S. Cissel, A. B. Roberts, P. Kondaiah, R. Lafyatis, M. B. Sporn, and K. Unsicker. 1991. Localization and actions of transforming growth factor- $\beta$ s in the embryonic nervous system. Development (Camb.). 113:183-191.

7. Potts, J. D., J. M. Dagle, J. A. Walder, D. L. Weeks, and R. B. Runyan 1991. Epithelial-mesenchymal transformation of embryonic cardiac endothelial cells is inhibited by a modified antisense oligodeoxynucleotide to transforming growth factor $\beta 3$. Proc. Natl. Acad. Sci. USA. 88:1516-1520.

8. Heine, U. I., E. F. Munoz, K. C. Flanders, L. R. Ellingsworth, H.-Y. P. Lam, N. L. Thompson, A. B. Roberts, and M. B. Sporn. 1987. Role of transforming growth factor $\beta$ in the development of the mouse embryo. J. Cell Biol. 105:2861-2876.

9. Miller, D. A., A. Lee, R. W. Pelton, E. Y. Chen, H. L. Moses, and R Derynck. 1989. Murine transforming growth factor- $\beta 2$ cDNA sequence and expression in adult tissues and embryos. Mol. Endocrinol. 3:1108-1114.

10. Miller, D. A., A. Lee, Y. Matsui, E. Y. Chen, H. L. Moses, and R. Derynck. 1989. Complementary cDNA cloning of murine transforming growth factor- $\beta 3$ ( TGF- $\beta 3$ ) precursor and the comparative expression of TGF- $\beta 3$ and TGF$\beta 1$ messenger RNA in murine embryos and adult tissues. Mol. Endocrinol. 3:1926-1934. 
11. Thompson, N. L., F. Bazoberry, E. H. Speir, W. Casscells, V. J. Ferrans, K. C. Flanders, P. Kondaiah, A. G. Geiser, and M. B. Sporn. 1988. Transforming growth factor beta- 1 in acute myocardial infarction in rats. Growth Factors. 1:9199.

12. Parker, T. G., K.-L. Chow, R. J. Schwartz, and M. D. Schneider. 1990. Differential regulation of skeletal $\alpha$-actin transcription in cardiac muscle by two fibroblast growth factors. Proc. Natl. Acad. Sci. USA. 87:7066-7070.

13. Roberts, A. B., N. S. Roche, T. S. Winokur, J. K. Burmester, and M. B. Sporn. 1992. Role of TGF- $\beta$ in maintenance of function of cultured neonatal cardiac myocytes: autocrine action and reversal of damaging effects of interleukin-1. J. Clin. Invest. 90:2056-2062.

14. Lefer, A. M., P. Tsao, N. Aoki, and M. A. Palladino. 1990. Mediation of cardioprotection by transforming growth factor- $\beta$. Science (Wash. DC). 249:6164.

15. Lindquist, S., and E. A. Craig. 1988. The heat shock proteins. Annu. Rev. Genet. 22:631-677.

16. Pelham, H. R. B. 1990 . Functions of the hsp 70 protein family: an overview. In Stress Proteins in Biology and Medicine. R. I. Morimoto, A. Tissieres, and C. Georgopoulos, editors. Cold Spring Harbor Laboratory Press, Cold Spring Harbor, NY. 287-299.

17. Morimoto, R. I. 1991. Heat shock: the role of transient inducible responses in cell damage, transformation, and differentiation. Cancer Cells $A$ Month. Rev. 3:295-301.

18. Currie, R. W., B. M. Ross, and T. A. Davis. 1990. Induction of heat shock response in rats modulates heart rate, creatine kinase and protein synthesis after a subsequent hyperthermic treatment. Cardiovasc. Res. 24:87-93.

19. Donnelly, T. J., R. E. Sievers, F. L. J. Vissern, W. J. Welch, and C. L. Wolfe. 1992. Heat shock protein induction in rat hearts. Circulation. 85:769-778.

20. Dillmann, W. H., H. B. Mehta, A. Barrieux, B. D. Guth, W. E. Neeley, and J. J. Ross. 1986. Ischemia of the dog heart induces the appearance of a cardiac mRNA coding for a protein with migration characteristics similar to heat-shock/ stress protein 71. Circ. Res. 59:110-114.

21. Knowlton, A. A., P. Brecher, and C. S. Apstein. 1991. Rapid expression of heat shock protein in the rabbit after brief cardiac ischemia. J. Clin. Invest. 87:139-147.

22. Salo, D. C., C. M. Donovan, and K. J. A. Davies. 1991. Hsp70 and other possible heat shock or oxidative stress proteins are induced in skeletal muscle, heart and liver during exercise. Free Radical Biol. \& Med. 11:235-246.

23. Low, I., T. Friedrich, and W. Schoeppe. 1989. Synthesis of shock proteins in fetal mouse myocardial cells. Exp. Cell Res. 180:451-459.

24. Delcayre, C., J.-L. Samuel, F. Marrothe, J. J. Mercadier, and L. Rappaport. 1988. Synthesis of stress proteins in rat cardiac myocytes 2-4 days after imposition of hemodynamic overload. J. Clin. Invest. 82:460-468.

25. Weber, L. A. 1992. Relationship of heat shock proteins and induced thermal resistance. Cell Proliferation. 25:101-113.

26. Li, G. C., and A. Laszlo. 1985. Thermotolerance in mammalian cells: a possible role of heat shock proteins. In Changes in Eukaryotic Gene Expression in Response to Environmental Stress. B. G. Atkinson and D. B. Walden, editors. Academic Press, Inc., Orlando, FL. 227-254.

27. Karmazyn, M., K. Mailer, and R. W. Currie. 1990. Acquisition and decay of heat-shocked-enhanced postischemic ventricular recovery. Am. J. Physiol. 259:H424-H431.

28. Laemmli, U. 1970. Cleavage of structural proteins during the assembly of the head of bacteriophage T4. Nature (Lond.). 227:680-685.

29. Hightower, L. 1980. Cultured animal cells exposed to amino acid analogues or puromycin rapidly synthesize several polypeptides. J. Cell. Physiol. 102:407-427.

30. Chomczynski, P., and N. Sacchi. 1987. Single-step method of RNA isolation by acid guanidinium thiocyanate-phenol-chloroform extraction. Anal. Biochem. 162:156-159.

31. Church, G., and W. Gilbert. 1984. Genomic sequencing. Proc. Natl. Acad. Sci. USA. 81:1991-1995.
32. Qian, S. W., P. Kondaiah, A. B. Roberts, and M. B. Sporn. 1990. cDNA cloning by PCR of rat transforming growth factor $\beta-1$. Nucleic Acids Res. 18:3059.

33. Dehnez, F., R. Lafyatis, P. Kondaiah, A. B. Roberts, and M. B. Sporn. 1990 . Cloning by polymerase chain reaction of a new mouse TGF- $\beta$, mTGF- $\beta 3$. Growth Factors. 3:135-145.

34. Fornace, A. J., I. Alamo, M. C. Hollander, and E. Lamoreaux. 1989. Induction of heat shock protein transcripts and B2 transcripts by various stresses in Chinese hamster cells. Exp. Cell Res. 182:61-74.

35. Whitfield, H. J., C. B. Bruni, R. Frunzio, J. E. Terrell, S. P. Nissley, and M. M. Rechler. 1984. Isolation of a cDNA clone encoding rat insulin-like growth factor-II precursor. Nature (Lond.). 312:277-280.

36. Robey, P. G., M. F. Young, K. C. Flanders, N. S. Roche, P. Kondaiah, A. H. Reddi, J. D. Termine, M. B. Sporn, and A. B. Roberts. 1987. Osteoblasts synthesize and respond to TGF-beta in vitro. J. Cell Biol. 105:457-463.

37. Roberts, A. B., M. B. Sporn, R. K. Assoian, J. M. Smith, N. S. Roche, L. M. Wakefield, U. I. Heine, L. A. Liotta, V. Falanga, J. H. Kehrl, and A. S. Fauci. 1986. Transforming growth factor type-beta: rapid induction of fibrosis and angiogenesis in vivo and stimulation of collagen formation in vitro. Proc. Natl. Acad. Sci. USA. 83:4167-4171.

38. Danielpour, D., L. L. Dart, K. C. Flanders, A. B. Roberts, and M. B. Sporn. 1989. Immunodetection and quantitation of two forms of transforming growth factor-beta (TGF-beta 1 and TGF-beta 2 ) secreted by cells in culture. $J$. Cell. Physiol. 138:79-86.

39. Flanders, K. C., N. L. Thompson, D. S. Cissel, E. Van Obberghen-Schilling, C. C. Baker, M. E. Kass, L. R. Ellingsworth, A. B. Roberts, and M. B. Sporn. 1989. Transforming growth factor- $\beta 1$ : histochemical localization with antibodies to different epitopes. J. Cell Biol. 108:653-660.

40. Wakefield, L. M., D. M. Smith, K. C. Flanders, and M. B. Sporn. 1988. Latent transforming growth factor- $\beta$ from human platelets. J. Biol. Chem. 263:7646-7654.

41. Flanders, K. C., D. S. Cissel, L. T. Mullen, D. Danielpour, M. B. Sporn, and A. B. Roberts. 1990 . Antibodies to transforming growth factor- $\beta 2$ peptides: specific detection of TGF- $\beta 2$ in immunoassays. Growth Factors. 3:45-52.

42. McCune, B. K., B. R. Mullin, K. C. Flanders, W. J. Jaffurs, L. T. Mullen, and M. B. Sporn. 1992. Localization of transforming growth factor- $\beta$ isotypes in lesions of the human breast. Hum. Pathol. 23:13-20.

43. Gospodarowicz, D., J. Moran, D. Braun, and C. Birdwell. 1976. Clonal growth of bovine vascular endothelial cells: fibroblast growth factor as a survival agent. Proc. Natl. Acad. Sci. USA. 73:4120-4124.

44. Arrick, B. A., A. L. Lee, R. L. Grendell, and R. Derynck. 1991. Inhibition of translation of transforming growth factor-beta 3 mRNA by its 5 ' untranslated region. Mol. Cell. Biol. 11:4306-4313.

45. Takenaka, I. M., and L. E. Hightower. 1992. Transforming growth factor$\beta 1$ rapidly induces $\mathrm{Hsp} 70$ and $\mathrm{Hsp} 90$ molecular chaperones in cultured chicken embryo cells. J. Cell. Physiol. 152:568-577.

46. Low-Friedrich, I., D. Weisensee, P. Mitrou, and W. Schoeppe. 1992. Cytokines induce stress protein formation in cultured cardiac myocytes. Basic Res. Cardiol. 87:12-18.

47. Eddy, L. J., D. V. Goeddel, and G. H. W. Wong. 1992. Tumor necrosis factor- $\alpha$ pretreatment is protective in a rat model of myocardial ischemia-reperfusion injury. Biochem. Biophys. Res. Commun. 184:1056-1059.

48. Brown, J. M., C. W. White, L. S. Terada, M. A. Grosso, P. F. Shanley, D. W. Mulvin, A. Banerjee, G. J. R. Whitman, A. H. Harken, and J. E. Repine. 1990. Interleukin 1 pretreatment decreases ischemia/reperfusion injury. Proc. Natl. Acad. Sci. USA. 87:5026-5030.

49. Logan, A., S. A. Frautschy, A.-M. Gonzalez, M. B. Sporn, and A. Baird. 1992. Enhanced expression of transforming growth factor $\beta 1$ in the rat brain after a localized cerebral injury. Brain Res. 587:216-225.

50. Roberts, A. B., and M. B. Sporn. 1993. Physiological actions and clinical applications of transforming growth factor- $\beta$ (TGF- $\beta$ ). Growth Factors. 8:1-9. 